darüber würden sowohl der Deutsche Bundestag als auch die Bürgerinnen und Bürger gerne häufiger mehr erfahren. Zumindest gibt sich Bundesaußenminister Steinmeier ambitioniert für seine Amtszeit, für die er eine „kritische Selbstüberprüfung“ der Außen- und Sicherheitspolitik ankündigte, die er "ganz bewusst nicht als klassischen innerministeriellen Prozess anlegen“ möchte, „sondern als Dialog des Auswärtigen Amtes mit den wichtigsten außen- und sicherheitspolitischen Stakeholdern unter Einschluss der Zivilgesellschaft". ${ }^{44}$ Letzteres bleibt zu

44 Auswärtiges Amt, Rede von Außenminister Frank-Walter Steinmeier bei der Amtsübergabe im Auswärtigen Amt am 17. Dezember 2013 (Berlin: Auswärtiges Amt, 2013). hoffen und nimmt auch nicht zuletzt die Zivilgesellschaft in die Pflicht, denn wie sagte es Bundespräsident Gauck bei der Münchner Sicherheitskonferenz: „Außenpolitik soll doch nicht eine Sache von Experten oder Eliten sein - und Sicherheitspolitik schon gar nicht. Das Nachdenken über Existenzfragen gehört in die Mitte der Gesellschaft. Was alle angeht, das soll von allen beraten werden. Dazu drängt uns immer wieder die Weltlage - in diesen Tagen die Ereignisse in Mali und in der Zentralafrikanischen Republik. “45

45 Joachim Gauck, Deutschlands Rolle in der Welt: Anmerkungen zu Verantwortung, Normen und Bündnissen - Bundespräsident Joachim Gauck anlässlich der Eröffnung der Münchner Sicherheitskonferenz am 31. Januar 2014 in München.

\title{
Security Sector Governance and Reform: Back to Basics
}

\author{
Albrecht Schnabel*
}

\begin{abstract}
Security sector reform (SSR) is an important element of interventions in transition societies. The article evaluates the concept of security sector reform and its application, and it draws lessons for future SSR activities. The article proceeds in three sections: first, the basic objectives and activities of SSR programmes and strategies are reviewed; second, challenges and lessons of applied SSR are elaborated; and, third, it is argued that most SSR activities are not implemented as intended and may even weaken their stated objectives. The article concludes with a plea for a return to SSR basics as well as a continuous engagement with the conceptual and practical development of SSR.
\end{abstract}

Keywords: Security sector reform, governance, transition societies

Sicherheitssektorreform, Governance, Transitionsgesellschaften

\section{Introduction}

A mong donor nations, support for security sector reform (SSR) is increasingly seen as a fundamental ingredient of ethically-driven and people-focussed interventions by bilateral and multilateral actors who assist transition societies, particularly those emerging from internal conflict, in building peace and stability. The normative agenda of SSR, a facilitator of consolidating democratic and good governance of the security sector, puts ethical commitments to respect accountability and clearly provide human security ahead of technical assistance.

SSR involves a range of activities that facilitate political and behavioural change and thus improve political stability and human security as well as human development and public safety. Its activities are carried out by local and national actors with - requested - international assistance. However, SSR can only meet its objectives if it is designed and implemented in line with its main principles; if it is directed at creating and supporting the conditions for legitimate and "good" security sector governance; and if it is not implemented in the guise of "pseudo-SSR" activities that resemble SSR in all but the name.

This article reviews the basic concept of security sector reform, its often half-hearted application to reform efforts that are all too

* Albrecht Schnabel is Senior Fellow in the Research Division of the Geneva Centre for the Democratic Control of Armed Forces (DCAF), where he works on security sector governance and reform, and peace processes. readily and inappropriately called "SSR", and lessons needed to inform future SSR activities. It is divided in three main sections: The first section briefly reviews the basic objectives and activities of security sector reform programmes and strategies. The second section reviews challenges and shares lessons of applied SSR, while the third section argues that more often than not SSR activities are not implemented as intended and run the risk of undermining their own objectives. The concluding comments call for a return to SSR basics and continuous engagement with the conceptual and practical evolution of SSR.

\section{On the Basics of Security Sector Reform ${ }^{1}$}

Among analysts and practitioners there is disagreement on the institutions and actors that resemble a nation's security sector, and on the characteristics of a security sector reform process. Helpful guidance is offered by the 2008 report on SSR by the UN Secretary-General, presenting a solid framework for a common, comprehensive and coherent approach by the United Nations and its member states, reflecting shared principles, objectives

1 The text in this section is based on: Albrecht Schnabel, "The SecurityDevelopment Discourse and the Role of SSR as a Development Instrument," in Albrecht Schnabel and Vanessa Farr, eds., Back to the Roots: Security Sector Reform and Development, Münster: LIT Verlag, 2012, pp. 49-54; and, by the same author, "Ideal Requirements versus Real Environments in Security Sector Reform", in Hans Born and Albrecht Schnabel, eds., Security Sector Reform in Challenging Environments, Münster: LIT Verlag, 2009, pp. 7-11. 
and guidelines for the development and implementation of SSR activities. ${ }^{2}$ The report notes that: "It is generally accepted that the security sector includes defence, law enforcement, corrections, intelligence services and institutions responsible for border management, customs and civil emergencies. Elements of the judicial sector responsible for the adjudication of cases of alleged criminal conduct and misuse of force are, in many instances, also included. Furthermore, the security sector includes actors that play a role in managing and overseeing the design and implementation of security, such as ministries, legislative bodies and civil society groups. Other non-state actors that could be considered part of the security sector include customary or informal authorities and private security services". ${ }^{3}$ Moreover, in the words of the report, "[s]ecurity sector reform describes a process of assessment, review and implementation as well as monitoring and evaluation led by national authorities that has as its goal the enhancement of effective and accountable security for the State and its peoples without discrimination and with full respect for human rights and the rule of law."4

Achieving good, democratic security sector governance (SSG) is a key objective of SSR. "Good" governance of the security sector draws on the key principles of good governance: participation, rule of law, transparency, responsiveness, consensus orientation, effectiveness and efficiency, and accountability. ${ }^{6}$ Good governance of the security sector is based on the conviction that, as former UN Secretary-General Kofi Annan noted in 1999, the security sector "should be subject to the same standards of efficiency, equity and accountability as any other [public] service". ${ }^{7}$ It is this spirit of a "culture of service" which is "promoting unity, integrity, discipline, impartiality and respect for human rights among security actors and shaping the manner in which they carry out their duties" ${ }^{8}$ Only then are societies assured that "the security institutions perform their statutory functions - to deliver security and justice to the state and its people - efficiently and effectively in an environment consistent with democratic norms and the principles of good governance and the rule of law, thereby promoting human security". 9

The main objectives of security sector reform are, first, to develop an effective, affordable and efficient security sector,

2 United Nations, "Securing Peace and Development: The Role of the United Nations in Supporting Security Sector Reform", Report of the SecretaryGeneral, UN Doc. A/62/659-S/2008/392, New York: United Nations, 3 January 2008. See also the 2013 follow-up report: United Nations, "Securing States and Societies: Strengthening the United Nations Comprehensive Support to Security Sector Reform", Report of the Secretary-General, UN Doc. A/67/970-S/2013/480, New York: United Nations, 13 August 2013.

3 Ibid, United Nations, 3 January 2008, para. 14.

4 Ibid, para. 17.

5 The text in this section is based on Albrecht Schnabel, "Ideal Requirements versus Real Environments in Security Sector Reform," in Hans Born and Albrecht Schnabel, eds., Security Sector Reform in Challenging Environments, Münster: LIT, 2009, pp. 4-7.

6 For the discussion on good governance and good governance of the security sector the author follows the definition of 'good governance' as provided by the UN Economic and Social Commission for Asia and the Pacific (ESCAP), available at http://www. unescap.org/pdd/prs/ProjectActivities/Ongoing/gg/ governance.asp. For an alternative yet similar definition by the World Bank, see http://www.adb.org/Documents/ Policies/Governance/gov300.asp?p=policies.

7 Kofi Annan, "Peace and Development - One Struggle, Two Fronts", address of the United Nations Secretary-General to World Bank staff, 19 October 1999 , p. 5.

8 United Nations, "Securing Peace and Development", para. 15(e).

9 United Nations, "Maintenance of International Peace and Security: Role of the Security Council in Supporting Security Sector Reform", concept paper prepared by the Slovak Republic for the Security Council open debate, UN Doc. S/2007/72, 9 February 2007. for example by restructuring or building human and material capacity; and, second, to ensure accountability through democratic and civilian control of the security sector, for example by strengthening the management and oversight capacities of government ministries, parliament and civil society organisations. In operational terms SSR covers a wide range of activities within five broad categories: ${ }^{10}$

- Overarching activities, such as security sector reviews and their development, needs assessments and development of SSR strategies and national security policies.

- Activities related to security- and justice-providing institutions, such as restructuring and reforming national defence, police and other law enforcement agencies as well as judicial and prison systems.

- Activities related to civilian management and democratic oversight of security and justice institutions, including executive management and control, parliamentary oversight, judicial review, oversight by independent bodies and civil society oversight.

- Activities related to SSR in post-conflict environments, such as DDR, control of small arms and light weapons, mine action and transitional justice.

- Activities related to cross-cutting concerns, such as gender issues and child protection.

Which security sectors need to be reformed? There is need for reform if the security sector - or some of its parts - is not inclusive, is partial and corrupt, unresponsive, incoherent, ineffective and inefficient and/or unaccountable to the public. The extent of the reform rarely involves a total overhaul. Certain components and aspects of a nation's security sector might be functioning quite well, while others might be in need of extensive improvements. Thus, identifying where, how and when individual components must be (re)built, restructured, changed and/or fine-tuned is an important initial step and requires a thorough assessment of the sector's roles, tasks and requirements in light of national and local assessments of society's security and development needs. SSR processes, therefore, vary from country to country with each SSR context being different and unique. Although it is important to recognize that local contexts are rarely easily comprehensible and clear-cut, and instead tend to overlap, interact, change and evolve, in very rudimentary terms one can differentiate between four general contexts which serve as entry points for and condition the implementation of SSR activities.

These contexts are characterized by situations of socio-economic development, democratic transition and consolidation, (postconflict) peacebuilding, and post-9/11 counter-terrorism. While they cannot be neatly separated and instead often overlap, these SSR contexts are characterised by unique topical contexts, rationales, purposes and specific challenges: For instance, in the context of socio-economic development, SSR supports the economic transition process through the enhancement of peace and stability, while the negative impact of unaccountable and ineffective security institutions and dependence on external assistance for security sector reform can be detrimental

10 These definitions have been elaborated by Hänggi and Scherrer, p. 15 
to sustainable development processes. The context of democratic transition and consolidation is characterized by political transition, which needs to go hand in hand with the depoliticization and professionalization of security forces and proper functioning of democratic civilian control mechanisms. The context of (post-conflict) peacebuilding is defined by efforts to transition from war to peace and engage in constructive conflict transformation and statebuilding, including the reconstruction of a peacetime security sector, management of ongoing protracted security problems as well as legacies of the past, and to secure local ownership of reform efforts instead of unsustainable reforms resulting from external imposition. The context of post-9/11 counter-terrorism leads some nations to redefine their national security requirements and strategies and is defined by the search for more effective management of new (asymmetrical) forms of conflict; while the main challenges include increasingly blurred lines between external and internal security and the need to balance enhanced effectiveness of security institutions with improved accountability. ${ }^{11}$

\section{Ambitious yet Realistic: The Challenging Implementation of SSR}

\section{Difficulties of applied SSR}

What are some of the more common problems and shortcomings that stand in the way of implementing security sector reform activities? In order to prepare for inevitable set-backs in implementing reforms, it is helpful to envision what could be an ideal environment for comprehensive security sector reform efforts: Ideal conditions for planning, launching and implementing SSR activities include a safe environment in which armed violence has been contained and, in particular in cases of post-conflict situations, former conflict parties have already disarmed and opted for peaceful means to compete for power and influence. All relevant stakeholders are interested in and committed to the pursuit of serious reform efforts. There is strong political leadership and support for even the most painful reform objectives. The priorities, terms and conditions of such activities have been developed and agreed with the involvement of all relevant stakeholders, particularly the national and local actors on whose shoulders the eventual success of long-term, sustainable security sector reform and governance will rest. External financial, technical and political commitments are assured and sufficient enough in volume and duration to allow the national and local owners of the SSR process to carry out lengthy and sustainable reforms. All security institutions are ready to assume the responsibilities assigned to them as constructive and legitimate security providers. They furthermore appreciate the necessity of - and thus accept and support - civilian and democratic control of their activities. They reach out to other security institutions as well as to oversight and management bodies within the overall security sector, in efforts to coordinate separate but complementary

11 See also Albrecht Schnabel, "Security Sector Reform as a Manifestation of the Security-Development Nexus? Towards Building SSR Theory", in Paul Jackson, ed., Handbook of International Security and Development, Cheltenham: Edgar Elgar Publishing, forthcoming. reform efforts. The executive and parliament are both willing and sufficiently capable to exercise their responsibilities in overseeing and managing the country's security institutions. An effective and informed community of civil society organisations joins government agencies and the parliament in governing the security sector and monitoring ongoing reform processes. ${ }^{12}$

Less favourable but not unusual characteristics of transition environments include corruption; impunity and inadequate steps to "deal with the past" and work on crimes committed during a past conflict; poverty; ongoing military conflict; ongoing structural violence; a prevalence of small arms and light weapons; incoherent donor funds and programmes; vested interests of donors that are counterproductive to local reform efforts; donor fatigue; "stolen" elections; lack of democratic traditions; a government's lack of political legitimacy and credibility; lack of public confidence in security providers; organised crime; national and regional resource conflicts; the presence of armed non-state actors; inadequate, poorly designed and ill-conceived peace agreements; insufficient levels of social capital; insufficiently developed and possibly oppressed civil society; and a lacking culture of accountability and transparency - and other principles of good security governance - among security institutions and oversight mechanisms. ${ }^{13}$ A comparative study of experiences with SSR programmes carried out in the Central African Republic, Colombia, the Democratic Republic of the Congo, Georgia, Morocco, Nepal, Sri Lanka and Timor-Leste ${ }^{14}$ suggests that "in part due to these obstacles SSR is often conducted in a partial and limited manner. All too often the focus lies on the modernisation of the armed forces, while little attention is paid to other security institutions or strengthening the institutional and legal frameworks that underpin accountability and good governance in the sector. Preparation for SSR is poor, as security sector reviews remain incomplete, are not conducted at all or are not followed up by concrete measures to implement the recommendations produced." 15

\section{Lessons from SSR practice}

If done right, and in adherence to its main principles, SSR can be a considerable blessing for transition societies. If done wrongly, it can be a curse. A number of specific suggestions might help ease the challenge of meeting the most basic SSR principles in difficult reform contexts, for both national actors and the donor community supporting local SSR efforts. They include the need to develop a keen understanding of the local security needs and priorities, and of the required capacities to address these in an effective and efficient manner; and a keen understanding of and active investments in improving the social, economic and political conditions underpinning national SSR initiatives. They also include the need to invest in securing buy-in and maintaining

12 These points have been discussed in Albrecht Schnabel and Hans Born, Security Sector Reform: Narrowing the Gap between Theory and Practice, SSR Paper (No. 1), Geneva: Geneva Centre for the Democratic Control of Armed Forces, 2011, pp. 16-17.

13 Schnabel, "Ideal Requirements versus Real Environments in Security Sector Reform", pp. 16-17.

14 Further cases have been studied in the context of an ongoing research project directed by the author of this article. The project is entitled "Tracking the Development Dividend of SSR" and is funded by DCAF and the Folke Berndadotte Academy, Sandöverken, Sweden.

15 Schnabel and Born, Security Sector Reform: Narrowing the Gap between Theory and Practice, p. 31. 
support of top decisionmakers; to achieve small and visible successes while not losing sight of long-term SSR objectives; to be realistic and communicate effectively on key objectives, resource requirements and targeted timelines of reform activities; to be transparent and openly communicate implementation plans, challenges, difficulties, but also successes; as well as efforts to be inclusive in the planning and implementation of SSR activities, while retaining a healthy sense of criticism and caution vis-à-vis international and local partners. ${ }^{16}$

Especially in post-conflict situations, it is important to plan SSR programmes in a conflict-, development-, and governancesensitive manner, ensuring that SSR is implemented in ways that, at the very least, do not increase the risk of further violence and instability or strengthen and prop-up unaccountable and possibly abusive institutions. Sometimes one might have to accept the fact that minimum requirements for SSR activities do not (yet) exist. Sometimes it might thus be better to focus on familiarization and sensitization activities that might help in generating knowledge on and interest in future efforts towards good security sector governance. Careful and thorough SSR assessments and reviews tend to be particularly helpful in identifying and utilising the best possible timing, entry points and priority tasks for SSR activities.

\section{Full, Partial and Pseudo-SSR: On the Temptation to Misuse the SSR "Label"}

Experience tells us that applied SSR rarely lives up to its proclaimed principles. It rarely incorporates reforms of several if not all security institutions, along with their respective state- and society-based oversight institutions, in a common pursuit of good governance principles. Instead, many SSR activities focus on single security institutions, sometimes without addressing governance aspects or rooting reforms in thoroughly assessed and inclusive security reviews. One can differentiate between three types of approaches to SSR: properly conceived and fullyembraced and implemented Full SSR; "light" or Partial SSR; and what could be termed Pseudo-SSR. ${ }^{17}$ Full SSR involved the reform of several if not all security-providing institutions and state and non-state oversight/management institutions. For example, this might involve police and military reform programmes along with training of a parliamentary security committee and civil society organisations. While not all of this can be achieved at once, long-term plans and objectives include a comprehensive and far-reaching reform agenda. In what could be termed Partial $S S R$, reforms focus on one institution only and resemble more traditional institutional reform programmes, such as police or defence reform. However, in order to deserve at least partial qualification as SSR, such efforts need to cover reforms of both a security providing institution and its respective oversight/ management mechanisms at state and non-state levels. Moreover,

16 Ibid, p. 50. See also Schnabel, "Ideal Requirements versus Real Environments in Security Sector Reform", pp. 30-32.

17 This distinction has been made in Schnabel and Born, Security Sector Reform: Narrowing the Gap between Theory and Practice, pp. 22-30 and Albrecht Schnabel, "The Security-Development Discourse and the Role of SSR as a Development Instrument", in Albrecht Schnabel and Vanessa Farr, eds., Back to the Roots: Security Sector Reform and Development, Münster: LIT Verlag, 2012, pp. 53-54. there should at least be attempts to think of the overall security needs of society, for instance by positioning reform efforts within the context of a previously negotiated national security plan and strategy. Finally, what could be termed Pseudo-SSR stands for activities that focus on primarily one security institution, with an emphasis on providing equipment, technical assistance and training, and by excluding the crucially important governance (management, oversight and accountability) dimension of SSR and plans for broader, SSR-type reform efforts. If the latter category is pursued, the population should realize that these are not SSR efforts, while national actors and the international community should refrain from labelling such reforms as "SSR".

Full SSR corresponds to the type of SSR that moves us beyond reforms of individual security institutions and helps a society "to turn a dysfunctional security sector into a functional one, with security and justice institutions performing their statutory functions - to deliver security to the state and its people - efficiently and effectively." ${ }^{18}$ However, "[i]t is crucial but not sufficient that the security forces perform their statutory functions efficiently and effectively; they must also conform to principles of good governance, democratic norms, the rule of law and human rights. Consequently, reforms aimed solely at modernizing and professionalizing the security force merely increase their capacity without ensuring their democratic accountability; they are not consistent with the SSR concept."19

Unfortunately the latter two approaches - Partial SSR and Pseudo-SSR - tend to be the rule rather than the exception when examining security-relevant reform activities carried out and supported by local, national and international actors. In the above-mentioned study on pursuing SSR in challenging environments, most of the case studies as well as solicited practitioner experiences confirmed the prevalence of Partial SSR and Pseudo-SSR, while an ongoing study on the linkages between SSR and development shows that consultative planning processes for SSR neglect to solicit and draw on inputs from development actors. ${ }^{20}$ Although SSR is meant to be a critical engine for economic and human development, human (direct and structural) security provision as well as democratization and the promotion of good governance principles, these objectives are rarely pursued or accomplished by reform activities that might be labelled SSR, but are not embedded in an overall SSR programme and strategy. This is problematic for the eventual success of SSR in bolstering good security sector governance. In the worst case Pseudo-SSR activities are deceivably sold as Full SSR domestically and internationally, falsely raising high expectations while merely putting into place structures, processes and institutions that slow down or prevent, rather than support, legitimate and human security-based transition processes.

To be sure, there is nothing wrong with pursuing, for a variety of practical reasons, a more traditional reform agenda that focusses primarily on one security institution and its governance mechanisms and institutions. Ideally, such defence or police

18 Fairlie Chappuis and Heiner Hänggi, "The Interplay between Security and Legitimacy: Security Sector Reform and State-Building", in Julia Raue and Patrick Sutter, eds., Facets and Practices of State-Building, Leiden/Boston: Martinus Nijhoff Publishers, 2009, pp. 44-45.

19 Ibid, p. 45

20 See Schnabel and Farr, eds., Back to the Roots: Security Sector Reform and Development. 
reform programmes, for instance, will trigger further discussions and negotiations about reforms of other security institutions, possibly even reform efforts that eventually span a range of security institutions and oversight bodies and develop into real security sector reform activities.

The full range of tasks and options ideally covered in SSR processes is undoubtedly comprehensive and demanding. Such broader efforts are unrealistic unless planned, prepared and implemented in collaboration with all relevant actors in a sensible, sequenced, phased and context-responsive strategy. SSR is a long-term exercise that needs to be carefully prepared and does not lend itself to quick-fix approaches, even though there are some aspects of a reform agenda that can be addressed fairly swiftly. Once a national security policy and strategy have been developed and an SSR agenda has been negotiated with all relevant actors, its implementation will be determined by continuously changing contextual conditions, such as changing threat environments, political and social developments, resource availability, donor behaviour, or the negotiation and implementation of peace agreements. Continuous monitoring and adaptation of initially agreed reform processes - without, however, weakening the reform objectives - will then offer the necessary flexibility to adapt to changing realities on the ground.

Taking a half-hearted Pseudo-SSR approach can of course be tempting; it might ensure quick approval by national actors who stand to lose influence, power and privileges as a result of more ambitious and fully-fledged SSR programmes. Yet, approaches that search for seemingly pragmatic solutions to politically difficult reforms are often counterproductive when it comes to achieving sustainable improvement of stability, security, peace and development.

It is important to ensure that activities proclaimed to resemble SSR are genuinely targeting the reform of the full security sector, focus on both effectiveness and accountability, are pursued as long-term processes, and are designed in a participatory and inclusive manner in collaboration with state and non-state actors, and with due respect for local ownership, among other key principles of SSR. Partial SSR activities that seek to evolve into Full SSR activities should receive all possible support, while PSeudo-SSR activities that do not meet these qualifications risk doing more harm than good and should thus be discouraged.

\section{Conclusion: The Need to Focus on SSR Basics in Planning and Implementation}

The basic logic of SSR is quite simple: The effectiveness and efficiency of the security sector can be improved by matching its institutions with realistic threat scenarios and national security priorities; and by ensuring accountability of the security institutions to state and non-state stakeholders, and thus society overall. As a result, a nation's stability, security and development prospects are improved. Security sector reform is a process towards assuring good security sector governance. However, this simple logic cannot easily be translated into well-supported policy programmes and individual reform activities. In SSR, the record of implementation often falls short of its original intentions.
Anyone involved in designing, implementing or undergoing SSR knows quite well that reforming the security sector is a very challenging process. However, recent trends of SSR practice point to an emerging inflation of SSR principles (by shortcutting fundamental SSR components in favour or quicker and easier short-term reforms) and of SSR rhetoric (by mislabelling limited technical institutional assistance as "SSR activities"). In addition, frustrations over the challenges of applied SSR have sparked a questionable second-generation debate calling for a fundamental rethinking of SSR principles, while ignoring years of careful and experience-driven SSR scholarship.

Both SSR analysts and practitioners need to contribute to and stay abreast of SSR's theoretical and practical evolution. The path of reform towards good security performance and governance is an ambitious, but by no means unrealistic process. Ideal reform contexts are rare, while it is difficult to envision good SSG without parallel success in political reforms. A number of developments make it difficult for SSR activities to succeed in facilitating long-term change. These include flawed conceptual understanding and application of the SSR concept; misapplication of the SSR 'label' for technical assistance or security assistance activities other than SSR; the failure to link SSR with larger peacebuilding goals such as development and democratic governance; the pursuit of PSeudo-SSR, i.e. the intentionally flawed and partial implementation of SSR principles; unrealistic expectations about the speed at which SSR activities are able to trigger and support sector-wide sustainable change; poor synchronization with SSR-related activities such as DDR or transitional justice; and insufficient external support.

Recent trends in the SSR debate ignore the ongoing evolution of SSR as a concept, while they prefer to engage in a futile, although seemingly pragmatic search for new, more manageable, SSR "generations". Stripping SSR of some of its most fundamental principles is however a counterproductive move, even if pursued with the well-meaning intention of making SSR "easier", more acceptable and less painful and challenging to all or some parties involved in reform efforts. Moreover, many if not all of the improvements of second-generation SSR over its supposed first-generation sibling have long been discussed, tested and incorporated into the mainstream SSR debate, policy planning and, increasingly, also its application on the ground. ${ }^{21}$ Smart

21 According to the claims by proponents of second-generation SSR, first-generation SSR is characterized by the following tendencies: It is "process oriented; rigid (assessment, consensus building, strategy design, implementation, review); tends to measures inputs; technocratic; shortterm; [supported by] short rotations of experts; works with like-minded actors, refuses to engage with unsavoury people (e.g. Islamists); [pursues an] ambitious liberal-democratic agenda". On the other hand, a supposed second-generation SSR needs to be: "results oriented; flexible, iterative (based on finding entry points, building on successes); focuses on service delivery, interim security measures; results oriented; [is] fundamentally political; [is considered to be a] generational process; [involves] longer-term deployments; [values] real local ownership; [needs to] engage with non-state justice and security providers; [and is] principled, but with more practical, humble expectations". See Geoff Burt, "Ottawa panel discusses the development of second generation SSR model", Security Sector Resource Centre, Ottawa, 9 March 2011, http://www.ssrresourcecentre.org/2011/03/09/panel-discussionin-ottawa-to-discuss-findings-of-the-future-of-ssr-ebook/. All of the demands for second-generation SSR have already been incorporated in the debate and practise of SSR during the past 10 years, as lessons have successfully been learned. In fact, the noted "needs for second-generation SSR" are core characteristics of current approaches to SSR design and planning, as reflected in both scholarship on SSR and many hands-on technical guidance materials produced by national, regional and international actors supporting national SSR processes. 
approaches to SSR can be pursued with comprehensive and principled objectives in mind: They need to be applied in phases that do not betray the eventual objectives of good SSG; honour local ownership of the process and its results; and take into account debilitating circumstances that require piecemeal rather than landslide approaches towards achieving the necessary buy-in and other supporting conditions, which in turn facilitate reasonably swift pursuits of even longer-term reform programmes and strategies.

Most importantly, helpful lessons (not necessarily "best practices") need to be generated to assist those involved in planning and embarking on new reform processes - and to advance the practical usefulness, political debate and academic scholarship on SSR as a technical, political and social process. While best practises of SSR planning and implementation are not widely assessed and discussed, past SSR activities should be studied more carefully. An evolving focus within the donor community on monitoring and evaluation of SSR activities and contributions is a positive sign, but only if such helpful feedback on applied SSR is used to facilitate honest learning and improvement.

If pursued as intended, SSR can play a constructive role in building legitimate states and safe societies. However, if only pseudo-SSR activities are pursued, the risk is great that good intentions result in more harm than good, illegitimate state institutions are strengthened and the peace, development and security dividends of transition processes - as well as affected beneficiary populations - will suffer as a consequence. Focussing on the basic principles and objectives of SSR should thus be the aim of all those committed to real and positive change in transition societies.

\title{
The EU Security Sector Reform Agenda: Between Democratic Security Governance and Internal Security Interests
}

\author{
Ursula C. Schroeder*
}

\begin{abstract}
The European Union has become deeply involved in international security sector reform (SSR) and security assistance efforts. This article examines the EU's activities in the field and discusses to what extent the EU has made good on the promises of its comprehensive SSR agenda in its external relations. To do so, it outlines the EU's diverging strategic goals in the field, maps the institutional arenas relevant to their implementation, and discusses three core challenges to the EU's activities: horizontal coordination across institutional arenas; vertical disconnects between the EU's strategic agenda and their implementation in the field; and larger political challenges that result from the coexistence of contradictory policy goals at the strategic level.
\end{abstract}

Keywords: European Union, Security Sector Reform, security assistance, Common Foreign and Security Policy, EU Internal Security Strategy

Europäische Union, Sicherheitssektorreform, Sicherheitshilfe, Gemeinsame Außen- und Sicherheitspolitik, EU-Strategie für innere Sicherheit

\section{Introduction}

$\mathrm{S}$ ecurity sector reforms (SSR) have become a prominent tool in the European Union's foreign policy repertoire: attempts to comprehensively reform or rebuild dysfunctional security sectors are now a crucial part of the EU's broader post-conflict stabilization and institution-building policies (see Council of the European Union 2003: 12; Council of the European Union 2008: 8). To support the reconstruction of effective and democratically governed security architectures in states in crisis or transition, the EU has engaged a wide range of civilian and military tools and instruments, both as part of its Common Security and Defence Policy (CSDP) and its broader conflict prevention and peacebuilding policies (see European Commission 2011;

* Dr. Ursula C. Schröder is Professor of International Security, Otto-SuhrInstitute for Political Science, FU Berlin.

This article has undergone a double-blind peer-review process.

The author would like to thank the anonymous reviewers and the editors for their valuable comments and suggestions.
Derks and More 2009 for overviews). Designed to foster specific international norms and standards concerning democratic oversight and control of the security sector, the EU's SSR activities are highly normative interventions that go beyond strengthening the technical capacities of a security sector. At the same time, however, the EU has also invested considerable resources into classical security assistance activities. Predominantly geared at enhancing the internal security of the Union, these measures build on security cooperation with non-member states to counter existing and emerging transnational threats that emanate from outside the EU's borders. Through political dialogue, strategic partnerships and agreements, the EU in particular seeks to enhance the crime-fighting, counter-terrorism and border management capacities of neighbouring states (see Council of the European Union 2010: 29f). This 'external dimension' of EU internal security policies has become particularly prominent in the context of the European Neighbourhood Policy and in the context of EU enlargement policies. 